\title{
An Approach to the Integration of College English Teaching and Mobile Learning
}

\author{
Huanhuan Li \\ Baoji University of Arts and Sciences, Baoji Shaanxi, 721013, China
}

Keywords: University, mobile English teaching, Ntegration

\begin{abstract}
College English is one of the most important subjects in the universities, but it also face more severe difficulties lately, not only the credit is reduced, but some false statements like "time-consuming and inefficient" appear, so how to improve and innovation teaching mode with time demands has become the subject for many teachers to solve. With the rapid development of mobile internet, mobile devices are widely used in the study, which has become the main channel for students to acquire information. The teaching method of combination of mobile and study in College English effectively improves the efficiency of teaching, compared with the traditional teaching method for mobile study. It has many incomparable advantages and characteristics, for example, it is convenient, fast, independent and effectively meets the personalized learning needs of the students, and mobile study and College English teaching also complement the fusion efficiency. This paper analyzes the functions and necessities of the integration of College English teaching and mobile study, and puts forward specific measures to integrate them so as to promote the effective development of College English education reform and further improve the quality and efficiency of College English teaching.
\end{abstract}

\section{Introduction}

With the continuous development of information technology, the use of mobile tool to expand the new teaching method of learning is gradually applied in college teaching, play an important role in the lives of college students, college students are the main user for mobile products, with strong ability to accept new things, so most college students are in mobile study. The function of many mobile devices, become an indispensable tool in the life of college students, teaching should effectively use the advantages of mobile devices, let the Assisted College English teaching be more active, fully combined with the actual situation of College English teaching, teaching English to develop scientific and rational integration of mobile study university teaching methods, encourage students whenever and wherever possible. Learning, improve the efficiency of College English learning, to realize the effectiveness of mobile study in College English teaching, this article combines on College English teaching and the mobile study pathway plays an important role in exploring.

\section{The Role of Mobile Study in College English Teaching}

\subsection{Promote the Development of the Theory of Teaching Reform}

Integration of mobile study in College English teaching widen the teaching reform, which is mainly manifested in the theoretical level and practical level, for the former, as a new teaching method of College English, mobile study in English teaching will lead researchers to the theoretical level and summarized, and the summary of the achievements of the inevitable will enrich the theory of teaching reform to the theoretical research, and then the effective implementation of enriching English teaching reform theory ${ }^{[2]}$. 


\subsection{Renewing the Reform View of College English Teaching}

The application of mobile study in College English teaching has updated many teachers' reform ideas. The concept of reform refers to participants' views on teaching reform and teaching reform. In the process of teaching reform in the traditional, many teachers believe that the key of the reform of College English teaching is mainly the classroom reform, and the key lies in the reform of classroom teaching method reform, but the reform of College English Teaching in mobile into study, the reform of College English teaching teachers thought change, mainly due to mobile study into English Teaching in the reform, teachers found that students acquire English knowledge in the reform and teaching reform of College English teaching is to effective improvement . At the same time, the mobile media also promote the College English teaching reform theory are implemented effectively in the teaching practice, such as the micro teaching method, video can not only vividly teaching students English knowledge, but also can ensure that students have enough time to watch the video of the English teaching, and achieve teaching purpose only in the fusion of mobile study.

\subsection{New Topics for the Reform of English Teaching}

The integration processof mobile study in College English Teaching reform with new topics,so call English mobile study mode, the mode is generated mainly with the teaching reform produced by fusion of mobile study, it is not only has the microcosmic study of school-based research aspects,but also has the macroscopic describes the implementation of each school mobile study, mobile study for the reform of English is a systematic process, the need to reform the problems of teachers involved in mobile study's thoughts systematically, in thepractice process of mobile study, how to combine English mobile study practice with network platform. The mobile study resources more convenient for students to use; how to establish the teaching mode of College English mobile study etc. If the above problem is a theoretical consideration of College English mobile study, then what is the role of mobile study in teaching reform in the actual mobile study process? At the practical level, College English mobile study has widened many ways to explore English knowledge for students, and English mobile study has been combined effectively with network platform. It also shows that, with the continuous development of the reform of College English teaching integration of mobile teaching, whether in practice or research level, there will be many problems in research in the teaching reform, and with the problem of scientific and rational, in-depth development and Research on the reform and practice of English mobile study prompt.

\subsection{The Necessity of the Integration of College English Teaching and Mobile Study}

At present, in response to the requirements of the Ministry of education, attaches great importance to the students in the English classroom learning situation, the combination of College English teaching and mobile teaching mode of study is the situation, to improve the students' subject status in the teaching of English has a very important role. First, mobile study teaching methods effectively cultivate the students' self-study ability. Because of the current college students for individual has a very strong pursuit, the students more love to carry out teaching activities through personalized learning, there is a high requirement for learning, while the mobile study is just to meet the requirements of the students, the English teaching method based on mobile study makes English more information and learning time and place more flexibility, and enable students to pay more attention to the learning method, could promote the enthusiasm to improve students' Autonomous English learning. Second, mobile study for students to create a good environment for students to practice speaking and writing, through the virtual environment can effectively strengthen the comprehensive English learning, their learned English knowledge applied to practical life, constantly improve their English practical ability. Third, the convenience of mobile study is in conformity with the characteristics of English learning. English learning is essentially based on the scientific and effective processing and processing of the meaning and context of English according to the contents taught by teachers, so that we can master more English knowledge and achieve the purpose of effective English free communication. The convenience of mobile devices to provide greater 
convenience for students, students can learn the knowledge of memory consolidation and use their spare time, and then strengthen the mastery of English knowledge, it is important to improve the English level of students with role.

\section{The Approach to the Integration of College English Teaching and Mobile Study}

\subsection{Strengthening English Vocabulary}

Message is an important communication way for college students, and teachers can use the form of SMS to improve students' English vocabulary practice. In the actual operation, the teacher may to send messages to students of English vocabulary in free SMS platform to students, send a few English words and sentences every day, let the students through the autonomous learning mode and the meaning of master pronunciation of English words, and enable students to use the English words and sentences for training, in second day, students can send new English words message for relevant exercises and help students easily review and memorize words and consolidate knowledge points. In this teaching method, we can help students expand their vocabulary and consolidate new words in related exercises and reading comprehension exercises, and improve the quality of English teaching.

\subsection{Pertinence to Improve the Content of Teaching}

Mobile study can effectively stimulate students' enthusiasm in mobile study, and students are in modern science and technology and the internet are more popular, so that teachers can grasp the psychology of students, encourage students to use information technology actively to English learning, and to acquire new knowledge of English using mobile software related, but not only is learning English knowledge in the textbooks. As a strong applied discipline, English should take targeted teaching methods to get rid of the traditional instilling teaching method and integrate extracurricular content into College English teaching, so that students can really like English Teaching in Experiencing English culture. Because mobile study has the characteristics of learning whenever and wherever possible, can effectively stimulate students' interest in English study, so that teachers can introduce the Related videos, movies and music to the students, so that students can download to watch and learn, and better able to watch a movie in the process of learning English knowledge, in addition, teachers you can organize the students regularly watch a Englishmovie, and after movie content, let the students discuss the cultural differences, can effectively improve the students' English ability and understanding ability in the course of the discussion.

\subsection{Improve Oral Ability Through Communication Platform}

The important goal of College English teaching is to improve students' listening, speaking, reading and writing abilities. In order to effectively improve students' English level, the most important thing is to enhance students' oral and writing skills training. Teachers can set up an English communication platform for students through QQ group. On this platform, middle school students can only use English to communicate and learn, it can be a way of speech, or a way of writing. This mobile English communication platform is very popular among students, not only can effectively improve students' oral English ability, but also can exercise students' writing ability, so that students can truly master English language. The main purpose of students' learning English is to communicate and communicate with others through language. Through the English communication platform, we can effectively improve students' English communicative ability and effectively improve the efficiency and quality of English learning.

\subsection{Constantly Changing the Role of English Teachers}

Mobile study can combine information technology with English teaching effectively. In order to ensure the quality and effectiveness of teaching, teachers need to play the role of researcher and guider for students. First of all, in order to effectively promote mobile study can achieve the purpose of teaching, teachers need to learn skills, methods, for each student's sexual attitudes and 
characteristics and time management for effective analysis, basic work and design links to the mobile study, has become a research student at mobile study in . Secondly, in the study of the differences between students, teachers also need to develop teaching methods for students. Mobile study needs to be implemented according to students' learning characteristics when selecting material, because students are more likely to be disturbed by outside class time, so the teaching method of speech or picture and text is more suitable. Finally, for students who have no self-control, teachers can adopt encouraging teaching methods, give students more praise and encouragement in class and life, and use mobile technology to evaluate and instruct students effectively, so as to stimulate students' enthusiasm in learning English.

\subsection{Guiding Students to Participate in Online Communication}

In order to effectively improve the students' communicative competence, teachers should guide and encourage students to actively participate in online communication activities. Teachers can through the establishment of WeChat group, the English topic discussed under the guidance of teachers, teachers in the course of the discussion will not be interrupted and the importance of students' talk, discuss the process and enhance the students to participate in the online exchange of confidence, through the discussion on the mode of cultivating students' active thinking, so as to achieve to improve students' English ability to express the target. In addition, teachers can also help students increase their social experience by making friends online. Teachers can also provide foreign friends to students, not only to ensure the purpose of student communication, but also to ensure the safety of students' friends. In this process, we need to pay close attention to students' psychological change and attach importance to the cultivation of English ability. Teachers can also provide students with resources of mobile devices, encourage students to take the initiative to use the Internet to find English knowledge and improve their English self-learning ability.

\section{Conclusions}

All in all, students need to master English is key subjects in college learning, it is helpful to improve the students' communicative ability, teachers should make full use of the advantages of mobile technology, continuous optimization and innovation of College English teaching mode, into the mobile study method for students, to stimulate students' enthusiasm for learning English, students can start from their own English learning needs, learning English and English to promote sharing of resources, to enable students to develop the habit of independent learning. The integration of College English teaching and mobile study can provide students with personalized development learning path, enable students to acquire English knowledge at anytime and anywhere, and enhance the development of College English teaching reform in China.

\section{Acknowledgements}

This research was financially supported by the twelfth batch of school grade teaching reform research project of Baoji University of Arts and Sciences and the application of mobile learning under College English flipped classroom teaching model (Grant NO. 17JGYB56).

\section{References}

[1] Ye Yu. Fusion mobile study on College English teaching reform, Southern occupation education journal, 2017, 7 (3): 93-98.

[2] Li Qian. Thousands of College English mobile study fusion of the new teaching mode based on, campus English magazine, 2017 (30): 36-36.

[3] Liu Xiaoli, Jing East. Explore, Chinese occupation technology education reform of College English teaching based on study mobile, 2016 (29): 90-96. 
[4] Shaw Yan, Chen Shuyuan. A trial analysis of the new model of College English Teaching under mobile study, test weekly, 2016 (92): 80-80.

[5] Wei Na. A trial analysis of the new college English teaching model integrating mobile study, Journal of Qiqihar Teachers College, 2017 (2): 122-123.

[6] Liu Shan. Application and research of flipped classroom teaching mode in ubiquitous mobile study in College English teaching. Journal of Chifeng University: Natural Science Edition, 2017, 33 (15): 25-30. 